\title{
University Partnership Program for Scintillator Materials Research
}

\author{
Cooperative Research and Development Agreement \\ Final Report
}

CRADA Number: FRA-2016-0052

Fermilab Technical Contact: Anna Pla-Dalmau

Summary Report

20 October 2020

Fermi National Accelerator Laboratory / Kirk and Pine Street / P.O. Box 500 / Batavia, IL 60510 / 630.840.3000 / www.fnal.gov / fermilab@fnal.gov Managed by Fermi Research Alliance, LLC for the U.S. Department of Energy Office of Science 


\section{NOTICE}

This report was prepared as an account of work sponsored by an agency of the United States government. Neither the United States government nor any agency thereof, nor any of their employees, makes any warranty, express or implied, or assumes any legal liability or responsibility for the accuracy, completeness, or usefulness of any information, apparatus, product, or process disclosed, or represents that its use would not infringe privately owned rights. Reference herein to any specific commercial product, process, or service by trade name, trademark, manufacturer, or otherwise does not necessarily constitute or imply its endorsement, recommendation, or favoring by the United States government or any agency thereof. The views and opinions of authors expressed herein do not necessarily state or reflect those of the United States government or any agency thereof.

Available electronically at http://www.osti.gov/

Available for a processing fee to U.S. Department of Energy and its contractors, in paper, from:

U.S. Department of Energy

Office of Scientific and Technical Information

P.O. Box 62

Oak Ridge, TN 37831-0062

phone: 865.576 .8401

fax: 865.576 .5728

email: mailto:reports@osti.gov

Available for sale to the public, in paper, from:

U.S. Department of Commerce

National Technical Information Service

5285 Port Royal Road

Springfield, VA 22161

phone: 800.553 .6847

fax: 703.605.6900

email: orders@ntis.fedworld.gov

online ordering: http://www.ntis.gov/ordering.htm 
In accordance with Requirements set forth in Article XII of the CRADA document, this document is the final CRADA report, including a list of Subject Inventions, to be forwarded to the Office of Science and Technical Information as part of the commitment to the public to demonstrate results of federally funded research.

CRADA number: $\quad$ FRA-2016-0052

CRADA Title: $\quad$ University Partnership Program for Scintillator Materials Research

Parties to the Agreement: Dominican University and Fermi Research Alliance, LLC

Sponsoring DOE Program Office(s): Office of Science - High Energy Physics

DOE Funding Commitment Table:

\begin{tabular}{|l|c|c|c|c|c|}
\hline & Year 1 & Year 2 & Year 3 & Year 4 & \\
\hline $\begin{array}{l}\text { Funding } \\
\text { Type }\end{array}$ & * In-kind & * In-kind & * In-kind & * In-kind & Totals \\
\hline $\begin{array}{l}\text { Dept. of } \\
\text { Energy }\end{array}$ & $<\$ 5,000$ & $<\$ 5,000$ & $<\$ 5,000$ & $<\$ 5,000$ & $<\$ 20,000$ \\
\hline Totals & $<\$ 5,000$ & $<\$ 5,000$ & $<\$ 5,000$ & $<\$ 5,000$ & $<\$ 20,000$ \\
\hline \multicolumn{4}{|l|}{} \\
\hline
\end{tabular}

\section{Abstract of CRADA work:}

The Scintillation Detection Development (SDD) group of the Particle Physics Division (PPD) at Fermi National Accelerator Laboratory (Fermilab) conducts research and development work in the field of materials that exhibit scintillation properties for use in particle detection and identification in nuclear and high energy physics experiments and applications. SDD has established a University Partnership Program for Scintillator Materials Research (Program), to facilitate collaboration with faculty and students from local universities.

The collaboration between the SDD group and Dominican University will address the development of new plastic scintillating materials in two ways:

3.1. Synthesis of new organic fluorescent compounds to test with plastics commonly used in scintillation applications

3.2. Preparation and testing of commercially available plastics known for their resilience to radiation and rarely used in scintillation applications

\section{Summary of Research Results:}


The following students from Dominican University came to Fermilab and carried out research under the objectives of this CRADA, in particular:

Study and development of a synthetic route for a benzoxanthene derivative of the following general structure, the substituent on the $\mathrm{N}$-atom could be slightly different as well as the presence of the methyl group on the "basic" benzoxanthene structure.

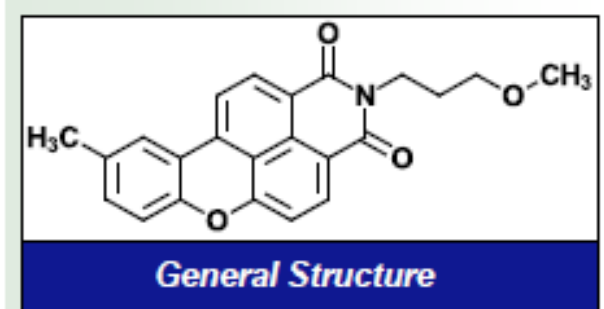

- Christopher Vazquez - 2016

- Jeanette Rojas - 2017

- Leslie Castillo - 2018

- Olivia Maj- 2019

- Christopher D. Vazquez - 2020

\section{Related Reports, Publications, and Presentations:}

Undergraduate Research, Scholarship, and Creative Investigations (URSCI) at Dominican University:

Christopher Vazquez - poster presented in 2017 at URSCI - Dominican University $\rightarrow$ Investigation of K27 Synthesis Step One: Condensation

Jeanette Rojas - poster presented in 2018 at URSCI - Dominican University $\rightarrow$ Investigation of K27 Synthesis (Step Three): Cyclization of APNA with Diazonium Salt

Leslie Castillo - poster presented in 2019 at URSCI - Dominican University $\rightarrow$ Investigation of K27: Step Three and Four

Olivia Maj - poster presented in 2019 at URSCI - Dominican University $\rightarrow$ K27: A Preparation of Fluorescent Organic Compounds

Christopher D. Vazquez - poster presented in 2020 at URSCI - Dominican University $\rightarrow$

Halogen-Substituted Benzoxanthene Derivatives

Annual presentations on R\&D at Fermilab:

James Freeman - February 2020 - Recent Activities in Calorimetry and Scintillators

James Freeman - May 2021 - 2020 Status on Calorimetry and Scintillator 
Subject Inventions listing:

None

Report Date: November 10, 2021

Technical Contact at Fermilab: Anna Pla-Dalmau

Partner POC Name and Email Address: Joseph Sagerer (jsagerer@dom.edu)

This document contains NO confidential, protectable or proprietary information. 